Int. J. Dev. Biol. 56: 605-611 (2012)

doi: $10.1387 / \mathrm{ijdb} .113474 \mathrm{tr}$

\title{
What Hydra can teach us about chemical ecology - how a simple, soft organism survives in a hostile aqueous environment
}

\author{
TAMAR RACHAMIM and DANIEL SHER* \\ Department of Marine Biology, Leon H. Charney School of Marine Sciences, University of Haifa, Israel
}

\begin{abstract}
Hydra and its fellow cnidarians - sea anemones, corals and jellyfish - are simple, mostly sessile animals that depend on bioactive chemicals for survival. In this review, we briefly describe what is known about the chemical armament of $H y d r a$, and detail future research directions where Hydra can help illuminate major questions in chemical ecology, pharmacology, developmental biology and evolution. Focusing on two groups of putative toxins from Hydra - phospholipase A2s and proteins containing ShK and zinc metalloprotease domains, we ask: how do different venom components act together during prey paralysis? How is a venom arsenal created and how does it evolve? How is the chemical arsenal delivered to its target? To what extent does a chemical and biotic coupling exist between an organism and its environment? We propose a model whereby in Hydra and other cnidarians, bioactive compounds are secreted both as localized point sources (nematocyte discharges) and across extensive body surfaces, likely combining to create complex "chemical landscapes". We speculate that these cnidarian-derived chemical landscapes may affect the surrounding community on scales from microns to, in the case of coral reefs, hundreds of kilometers.
\end{abstract}

KEY WORDS: chemical-ecology, Hydra, phospholipase A2, ShK domain

\section{Introduction}

Back in the wild-and-wooly days of the old American west, the Colt revolver earned the nickname "the great equalizer", because it would allow any person -as weak as he or she might be - to survive in the dangerous and hostile environment of thugs, highwaymen and Clint Eastwood. Panning from the main street of the ghost town to a crevice under a nearby desert rock, the camera of the Western movie might catch a similar drama: a slow scorpion waiting in ambush to catch its faster, more alert and physically stronger prey, or the inverse - a jackal attacking a slow desert toad but immediately dropping it and retreating in convulsions. In both cases the "great equalizer" is chemical in nature - a venom or chemical defense system.

Cnidarians, and Hydra in particular, are one of the most extreme cases of "the great equalizer" - they are morphologically simple, soft bodied and sessile organisms surviving in an aquatic environment infested with potential predators, competitors and pathogenic organisms. Furthermore, most cnidarians are active predators, feeding on prey such as arthropods and fish that are fast, alert and well protected. For this reason, the chemical ecology of cnidarians, and especially their toxic chemical armament, has been intensely studied for several decades. With the sequencing of its genome (and that of another cnidarian, the sea anemone Nematostella vectensis (Chapman et al., 2010, Putnam et al., 2007) and the introduction of modern genetic techniques such as gene knock-down and transgenesis, Hydra is poised to become an important model organism in chemical ecology. In this review, we will briefly outline what is known about the toxic chemical armament of different Hydra species, focusing on the venom used to catch prey and defend against predators. More importantly, we aim to describe several ways in which Hydra can help understand how toxins and venoms evolve, how they are deployed and how they can affect marine ecosystems.

\footnotetext{
Abbreviations used in this paper: CRISP- cystein rich secretory protein; Hmpl- Hydra metalloproteinase 1; PLA2- phospholipase A2.
}

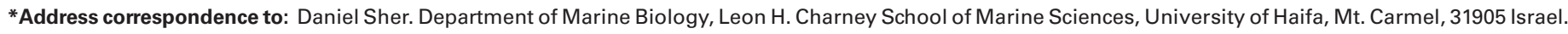
Tel: +972-4-824-0731. Fax: +972-4-828-8267. e-mail: dsher@univ.haifa.ac.il

web: http://marsci.haifa.ac.il/index.php?option=com_content\&view=article\&id=167\&ltemid=48\&lang=en
}

Final, author-corrected PDF published online: 5 June 2012

ISSN: Online 1696-3547, Print 0214-6282 


\section{What constitutes the chemical armament of Hydra?}

Given the long history of Hydra as a research model, dating back to studies by Abraham Trembley (Trembley, 1744), it is surprising how little is known about the chemical arsenal of Hydra, especially in comparison to other cnidarians such as sea anemones (Moran et al., 2009a) (see also the special issue on cnidarian toxins and venoms in Toxicon 54, 2009). Initial studies of Hydra venom focused on describing the physiological effect of the venom on model organisms such as Drosophila, which simulate arthropod prey, and on isolated heart muscle. When injected into Drosophila, Hydra nematocyst venom causes a rapid spastic paralysis followed by a long phase of flaccidity (Weber et al., 1987, recently reviewed by Sher and Zlotkin, 2009). The latter, flaccid stage might help the Hydra manipulate the paralyzed prey, which may be as large as the Hydra itself, while engulfing it. The venom also has an inotropic effect, increasing the contraction force of vertebrate myocardium (Lesh-Laurie et al., 1989). The venom does not have strong tissuedegrading activity, suggesting that, unlike snake venoms (Fry and Wuster, 2004, Thomas and Pough, 1979), it does not initiate the digestion process.

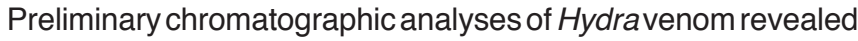
the occurrence of at least two differet protein toxic fractions, one causing spastic paralysis and hemolysis and the second causing long-lasting depressant paralysis (Klug et al., 1989b), however neither of these has been isolated and characterized to date (Sher and Zlotkin, 2009). Recent approaches making use of the ever-increasing amount of genetic data available have revealed the occurrence of transcripts with a high level of homology to at least eight groups of previously-described toxins (Sher et al., 2005b, Sher and Zlotkin, 2009). Two of these, actinoporins and ShK-domain containing proteins, have been shown to be associated with nematocysts (Hwang et al., 2007). Actinoporins are 20 $\mathrm{kDa}$ cytolytic and lethal proteins common in sea anemones, which have been intensively studied to understand protein-membrane interactions (Anderluh and Macek, 2002, Edwards et al., 2002), whereas the ShK domain may block $\mathrm{K}^{+}$channels (Rangaraju et al., 2010 and see below). In addition, we have recently detected using mass spectrometry putative neurotoxic phospholipase A2 proteins in the nematocyst content, in agreement with biochemical analyses of the venom (Weber etal., 1987) (see below). Importantly, through millions of years of evolution, most venomous organisms have come to rely on complex chemical mixtures, rather than on one or two molecules, to catch their prey or defend themselves from predators. "Simple" venom, such as that produced by the honey bee, contains around 30 types of molecules (Peiren et al., 2005), whereas scorpion, spider or cone snail venom can contain hundreds and even potentially as much as one thousand different components (Escoubas etal., 2008). Thus, it is likely that additional families of toxins, potentially with novel functions or molecular folds, await discovery.

While our understanding of Hydra venom is still very patchy, the emergent picture is that of a venom cocktail different from that of many other venomous organisms studied to date. Ambush predators such as sea anemones, scorpions and cone snails need to immediately paralyze their prey, and this paralysis is caused
Fig. 1. Recruitment of type III phospholipase A2 proteins to animal venoms: a case of convergent evolution? (A) $A$ maximum likelihood phylogenetic tree is shown of the catalytic type III PLA2 domain from cnidarians, arthropods and deuterostomes (hemichordates, cephalochordates and vertebrates), with venom proteins highlighted by a thick branch, bold text and an icon of the producing organism. The organisms are color coded as follows: blue=cnidarians, red=arachnids, black=insects, green=deuterostomes. The tree was produced using PhyML, numbers above the branches denote aLRT confidence (Anisimova and Gascuel, 2006, Guindon and Gascuel, 2003). The sequences used to construct the tree can be divided into three major clades: The first contains PLA2s from a variety of organisms, and we propose that these represent ancestral PLA2s involved in arachidonic acid metabolism and through this pathway in multiple forms of endogenous signaling (Schaloske and Dennis, 2006). The second clade contains mainly known venom proteins, and we propose that these sequences may have undergone convergent evolution favoring a paralytic-neurotoxic rather than enzymatic activity. Finally, a third clade may represent salivary-gland PLA2s, although most of these sequences originate from sequenced genomes and their biological role is still unknown. (B,C) Immunohistochemical detection of a similar PLA2 on the tubules of undischarged (B) and discharged (C) nematocysts from the jellyfish Rhopilema nomadica. Bars: $2 \mu \mathrm{m}$ in (B), $1 \mu \mathrm{m}$ in (C). The images are from (Lotan et al., 1995), reprinted by permission from Macmillan Publishers Ltd, Nature, copyright 1995.

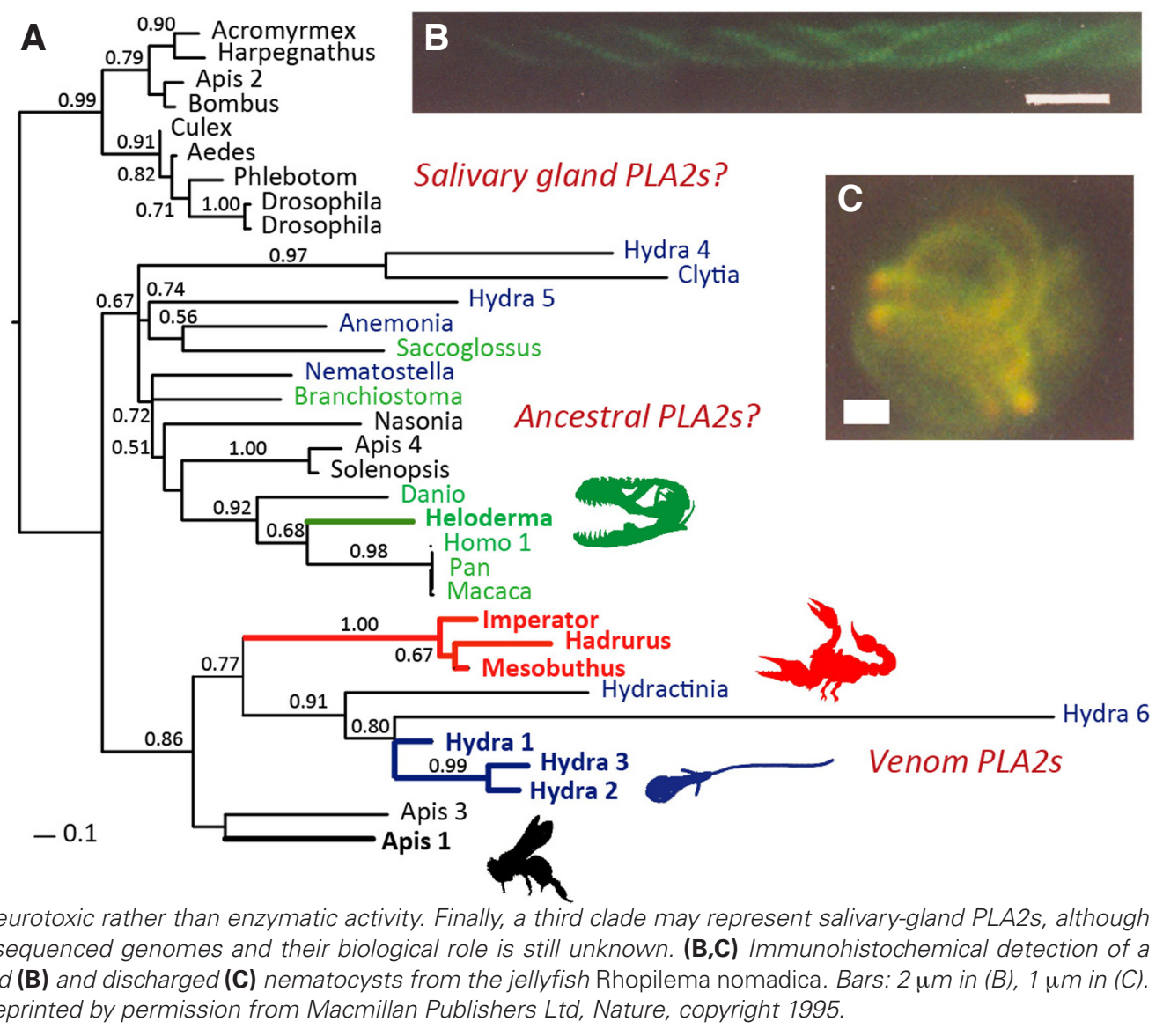


mainly by short (4-7kDa) peptide neurotoxins (Fry et al., 2009, Moran et al., 2009a, Morgenstern et al., 2011, Olivera, 2002, Terlau et al., 1996). Typically tens or even hundreds of such peptide neurotoxins are found in every venom cocktail, with different neurotoxins evolving to interfere with nerve and muscle activity at many different locations (e.g. pre- and post-synaptic ion channels, neurotransmitter receptors) (Fry et al., 2009). From an ecological standpoint, Hydra belongs to this group of organisms, yet to date no genes or transcripts have been detected encoding short peptide neurotoxins (Sher et al., 2005b, Sher and Zlotkin, 2009), and biochemical fractionation of the nematocyst venom supports the lack of low molecular weight ( $<20 \mathrm{kDa}$ ) toxins (Klug et al., 1989a).

\section{How does Hydraparalyse its prey without using peptide neurotoxins?}

Part of the neurotoxicity of the venom is likely due to the abovementioned proteins containing ShK domains (Hwang et al., 2007, Rangaraju et al., 2010) as well as to neurotoxic PLA2s. Additional toxins, for example a large (>100 kDa) neurotoxin (which potentially also has cytolytic activity), are known to be found in the venom (Klug and Weber, 1991, Klug et al., 1989a) but await identification and characterization. However, the total effect of the venom is likely more than a simple sum of the activities of its various molecular components, with venom components acting in synergy at various levels. At the molecular level, toxins can interact among themselves (or with non-toxic venom components) by allosterically modulating their binding to the relevant molecular target (Cohen et al., 2006). At the cellular level, toxins can synergize by affecting complementary targets on the nerve or muscle fibers, for example through opening $\mathrm{Na}+$ channels and blocking $\mathrm{K}+$ channels which can lead to a "lightning-strike"-like tettanic paralysis (Terlau et al., 1996). Finally, different components can interact at the system level, for example with tissue-disrupting components or components increasing vascular permeability enhancing the accessibility of neural tissue, or by affecting many critical systems in parallel (Gutierrez et al., 2010, Wullschleger et al., 2005).

Are all of the toxins needed to capture the prey, or are there "core" toxins critical to venom activity? What is the role of nonparalyzing proteins (e.g. some types of hemolysins)? It is here that Hydra as a

Fig. 2. ShK toxin-like domains: recurring features in venom-related and other proteins. Schematic illustrations are shown of ShK-domain containing proteins and of their corresponding gene structures. The proteins are all drawn to the same scale, but the gene structures are not. The full length of the ShKCLec protein is 1004 amino acids. The break in the gene model of HMP3 represents an unsequenced region of the genomic contig. Red exons are those encoding ShK domains. The gene model accession numbers in the Hydra genome are as follows: HMP3Hma2.228615, SCP-ShK-Hma2.204028, ShKCLec - Hma2.206417, HMP1 - Hma2.217198, HMP2-Hma2.214401, HMP4-Hma2.228188. model organism has a unique power to help unravel the complexity of venom and dissect the role of specific venom components. This can be done through experimentally manipulating the venom composition by knocking down the expression of specific toxin genes (e.g. Chera et al., 2006, Lohmann et al., 1999 and others).

\section{How did the chemical armament of Hydra evolve?}

Venoms from vastly differentorganisms - cnidarians, arthropods, snails and snakes - have similar molecular components, yet it is highly unlikely that the last common ancestor of all metazoans was venomous (Fry et al., 2009). How does a venomous organism "assemble its arsenal" (Fry and Wuster, 2004)? What are the basic molecular building blocks of venom, and where do they originate from? The current view of venom evolution suggests that toxins are often born when a gene encoding a protein involved in some aspect of the normal physiology of an organism is recruited and expressed in the venom gland (Fry et al., 2009, Fry and Wuster, 2004). Such toxin genes are often replicated, for example by unequal crossover and recombination (Moran and Gurevitz, 2006, Moran et al., 2009b, Moran et al., 2008), to form multigene families. The various members of these genes can then either follow different evolutionary trajectories, often diversifying to form "combinatorial libraries" (Conticello et al., 2001, Olivera, 2002, Sollod et al., 2005), or conversely they can undergo "concerted evolution" which resists diversification and may facilitate high expression levels of important, functionally conserved, toxins (Moran et al., 2008).

\section{Type III secretory phospholipase A2s (PLA2s)}

PLA2s are one of the first cnidarians venom proteins unequivocally shown to be injected by the nematocysts (Fig. 1 B,C; Lotan et al., 1995; Lotan et al., 1996), and are a good example of a protein scaffold that has been recruited multiple times into venom systems (Fry et al., 2009). Using tandem mass spectrometry, we
Protein
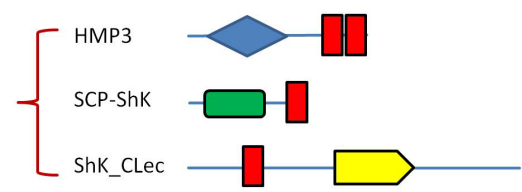

HMP1

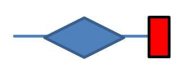

Foot regeneration HMP2

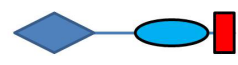

Unknown $\left\{\begin{array}{l}\text { HMP4 } \\ \text { Hma2.209939 }-\square \square \square\end{array}\right.$ Domain legend $200 \mathrm{AA}$ ShK SCP/CRISP C-type lectin MAM

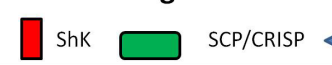

Gene structure
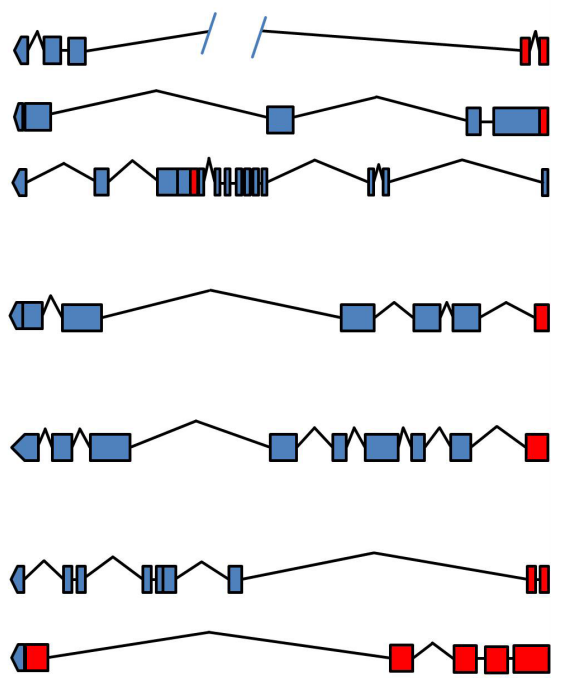
have detected three different type III PLA2 proteins in extracts from Hydra magnipapillata nematocysts. These PLA2s are similar, on the one hand, to toxins found in bee, lizard and jellyfish venoms (Lotan et al., 1995, Lotan et al., 1996, Sher et al., 2005b), and on the other hand to mammalian PLA2s expressed in kidney, heart, liver and muscles (Valentin et al., 2000) (Fig 1A). In addition to the nematocyst PLA2s, the Hydra genome contains another three putative genes containing similar PLA2 domains, whose role is currently unclear (Fig 1A). Interestingly, the Hydra nematocyst PLA2s are more similar, in terms of their sequence, to venom PLA2s from scorpions and bees than the other PLA2 genes in the Hydra genome, or to type III PLA2 genes from other cnidarians such the hydrozoan Clytia hemispaerica and the sea anemones Nematostella vectensis and Anemonia viridis (Fig. 1A). Future studies are needed in order to determine whether the sequence similarity between venom PLA2s from different organisms represents convergent evolution of proteins originating from a similar scaffold towards a neurotoxic-paralytic activity rather than purely an enzymatic one.

\section{Toxins with ShK-like domains}

A second putative toxin, detected by Hwang and co-workers (Hwang et al., 2007) as a nematocyst-specific transcript, encodesa protein, which has a ShK-like domain (Fig. 2). ShK is a member of a group of peptide anemone toxins that block $\mathrm{K}^{+}$channels. When found in the context of a larger protein, the ShK domain may still bind and block $\mathrm{K}^{+}$channels, and as a non-venom, "endogenous" protein has been suggested to regulate the density of $\mathrm{K}^{+}$channels on the plasma membrane by trapping the channels in the endoplasmic reticulum (Rangaraju et al., 2010). The protein detected by Hwang and co-workers contains, in addition to a single ShK domain, also a second cysteine-rich domain (SCP or CRISP domain). A similar domain is found in many proteins potentially involved in pathogenesis, although its role is not clear. Additionally, more distant SCP/ CRISP domains are found in several toxins from wasps, lizards, snakes and cone snails (Hwang et al., 2007, Sher et al., 2005b). In addition to this putative toxin, we have detected another three proteins in the nematocyst extract containing one or more ShK-like domains. Two of these proteins contain a zinc metalloprotease domain, and the third contains, in addition to a non-canonical ShK domain, also a C-type lectin domain (Fig. 2). Both these domains ( $\mathrm{Zn}$ metalloproteases and C-type lectins) are common in snake venoms (Fry et al., 2009, Fry and Wuster, 2004). These proteins are good candidates for new families of cnidarian neurotoxins, and we are currently attempting to recombinantly express them and test whether they have the anticipated paralytic activity.

In all of these cases, the ShK domains are encoded by a separate exon, and at least 20 additional exons encoding this motif are found in the Hydra genome (Fig 2). These ShK-domain encoding exons may provide a "venom recruitment shortcut", as secreted proteins into which these exons are integrated will, most likely, bind $\mathrm{K}^{+}$channels found on excitable tissue - the main target of neurotoxins. A similar mechanism, where a $\mathrm{K}^{+}$channel toxin "leads" a PLA2 to nerve terminals, focusing the PLA2 enzymatic membrane-deforming activity on excitable tissue, has been suggested to underlie the potency of the snake toxin -bungarotoxin (Montecucco and Rossetto, 2000, Rowan, 2001).

\section{Hydra metalloproteinase 1 (HMP1)}

Finally, one of the ShK-domain-containing proteins we have detected in Hydra nematocyst extracts, Hydra Metalloproteinase 1 (HMP1), has previously been shown to be involved in head development (Yan et al., 1995; Yan et al., 2000), also see in this issue (Sarras, 2012). Future work is needed to both test whether HMP1 exhibits some form of toxic activity and to reconcile our observation of this protein in nematocyst extracts with its immunohistochemical localization to the extracellular matrix and endodermal cells in previous studies (Yan et al., 2000, Yan et al., 1995). However, if indeed HMP1 is a bona-fide venom protein, it may represent an early stage in the recruitment of proteins to venom, where the same protein fulfills both the ancestral, developmental, role and a new role in prey paralysis.

\section{How does Hydra deliver toxins to its target?}

Like all cnidarians, Hydra have evolved in their stinging cells, an amazing apparatus named nematocyst, to deliver their toxic chemistry into the target organism. These "high-tech cellular weaponry" systems (Tardent, 1995) are in essence sub-cellular nano-syringes, capable of explosively punching into the prey cuticle at accelerations of up to one million $g$ (Holstein and Tardent, 1984, Nuchter et al., 2006), see in this issue the review by Beckmann and Ozbek (2012). Hydra produce four nematocyte types, each of which is postulated to have a different biological role: large stenoteles and smaller desmonemes are organized in batteries and are involved in prey capture; holotrichous isorhizae are distributed all over the Hydra's body, and are used for defence of the Hydra against predators, and atrichous isorhizae are not used at all against target organisms; instead, these adherent nematocytes are used for locomotion (Ewer, 1947, reviewed in Sher and Zlotkin, 2009). Previous studies have suggested that two of these nematocyst types, stenoteles and holotrichous isorhizae, contain hemolytic proteins (Klug et al., 1989a), and recently it has been shown that each of these nematocysts contains a different actinoporin-like toxin (Hwang et al., 2007). Thus, it is likely that different nematocysts contain different toxins, and that Hydra in fact may have two venoms rather than one - one for catching prey and one for predator deterrence, each delivered by different nematocytes. Hydra now provide an excellent platform with which to study the adaptation of venom to specific ecological roles, although efficient methods must first be developed to separate nematocysts into different types to enable functional analyses of the venom (e.g. Wiebring et al., 2010).

The fascinating details on how nematocysts are built, how they function and how they are integrated into the nerve network of cnidarians are reviewed elsewhere (Tardent, 1995; Kass-Simon and Scappaticci 2002; David et al., 2008; Beckmann and Ozbek, 2012). As the developmental processes controlling the assembly of these complex secretory structures are slowly coming to light, it will be interesting to determine when and how the toxins are incorporated into the nematocyst (when and how the "gun is loaded"). Additionally, toxins (like any other protein) have a limited "shelf life", yet nematocysts can be stored intact in the cnidarian tissue and ready to fire, for extensive periods of time, presumably without the venom losing significant activity. Does Hydra possess specific 
molecular mechanisms to retain the activity of the "loaded" venom? Are there quality control mechanisms monitoring the venom to make sure its components are appropriately folded? Answers to such questions may, beyond their scientific value, also have important biotechnological applications.

\section{Can the chemical armament of a cnidarian affect the environment at different scales?}

So far, we have discussed Hydra venom assuming it is delivered by the nematocysts as a "point source", locally injected into the target organism. However, several studies suggest that nematocysts-derived compounds act as "feeding hormones", initiating the feeding response (Burnett et al., 1963), and inhibiting the discharge of additional nematocysts once the Hydra is satiated (Ruch and Cook, 1984). Since Hydra are often found in nature as dense patches (Elliott et al., 1997), such signalling may also occur between individuals, facilitating group responses, for example to a dense patch of zooplankton prey. Furthermore, if these venom components can be sensed by Hydra's prey, these could act as "predator-released kairomones", causing the prey to change behaviour and potentially avoid predation (Blaustein et al., 2010, Fainzilber et al., 1994).

From a wider perspective, the chemical arsenal of Hydrais much wider and more complex than the nematocyst-derived venom. Hydra produce a multitude of potentially bioactive compounds, including hemolysins likely involved in digestion (Sher et al., 2008, Sher et al., 2005a, Zhang et al., 2003), other potential pore-forming proteins involved in development and immunity (Amimoto et al., 2006, Miller et al., 2007, Sher and Zlotkin, 2009), neuropeptides and signaling peptides (Bosch and Fujisawa, 2001, Bottger et al., 2006, Takahashi et al., 1997), see in this issue (Fujisawa and Kayakawa, 2012; Pierobon, 2012) and several antimicrobial peptides (Augustin et al., 2009, Fraune et al., 2010). These proteins and peptides are produced by different body regions or cells, and several are secreted either into the gastrovascular cavity (Sher et al., 2008), into the developing oocyte or onto the ectodermal surface (Fraune et al., 2010). Importantly, when a signal is secreted from one location and diffuses or is transported to another, gradients are formed, and these gradients can convey information, for example during development and morphogenesis (Bosch and Fujisawa, 2001). Such gradients can mediate localized interactions between Hydra and its associated microbiota, for example by limiting bacterial load or modulating the composition of the microbial population in specific body regions (Fraune et al., 2010, Fraune and Bosch, 2007). We therefore propose that bioactive chemicals secreted both as "point sources" (e.g. discharged nematocysts) and across larger epithelial regions form concentration gradients and combine to create complex "chemical landscapes" (Fig. 3). These chemical landscapes form the micron-scale environments in which Hydra and its associated microbiota interact.

Finally, how far does the "chemical sphere of influence" of Hydra - and other cnidarians - extend? To what extent are the microenvironments of Hydra coupled to the ecosystem at larger scales? The usefulness of tiny Hydra to study such large-scale questions may seem questionable at first; however, as predators in aquatic environments, the potential of Hydra to affect prey densities and zooplankton population structure has already been suggested (Elliott et al., 1997, Link and Keen, 1995). Furthermore, Hydra harbour specific microbial communities, which differ between species and likely also differ from that of the surrounding water (Fraune and Bosch, 2007). As benthic animals, Hydra can therefore serve as "microbial refuges", and when they detach and become planktonic (Elliott et al., 1997, Reisa, 1973), their associated microbiota may inoculate new regions of the water body, mediating bacterial dispersion (Grossart et al., 2010). Finally, other cnidarians such as soft corals have been shown to release sufficient bioactive compounds into the water to reach concentrations which potentially affect surrounding microbes or the settlement of larvae of competing species (Krug, 2006). Through these three mechanisms - selective predation, microbial coupling and direct chemical influence -, Hydra can potentially have far reaching ef-
Fig. 3. Schematic representation of the "chemical landscape" produced by secreted bioactive proteins in Hydra. (A-D) Examples of genes encoding antimicrobial and cytolytic peptides and proteins expressed in different regions of Hydra. (A) Periculin 1A, an antimicrobial peptide which modifies the microbial community, is expressed in the female germline of adult Hydra vulgaris, as well as in developing embryos (not shown). (B) Hydralysins expressed in the endodermal digestive cells of Hydra viridissima, encode paralytic and cytolytic pore-forming proteins that are secreted upon feeding into the gastrovascular cavity. (C) Hy-MAC encodes a protein containing a MAC-PF pore-forming domain, it is expressed in gland cells throughout the body of Hydra magnipapillata. (D) Anklet also contains a MAC-PF domain, Anklet is
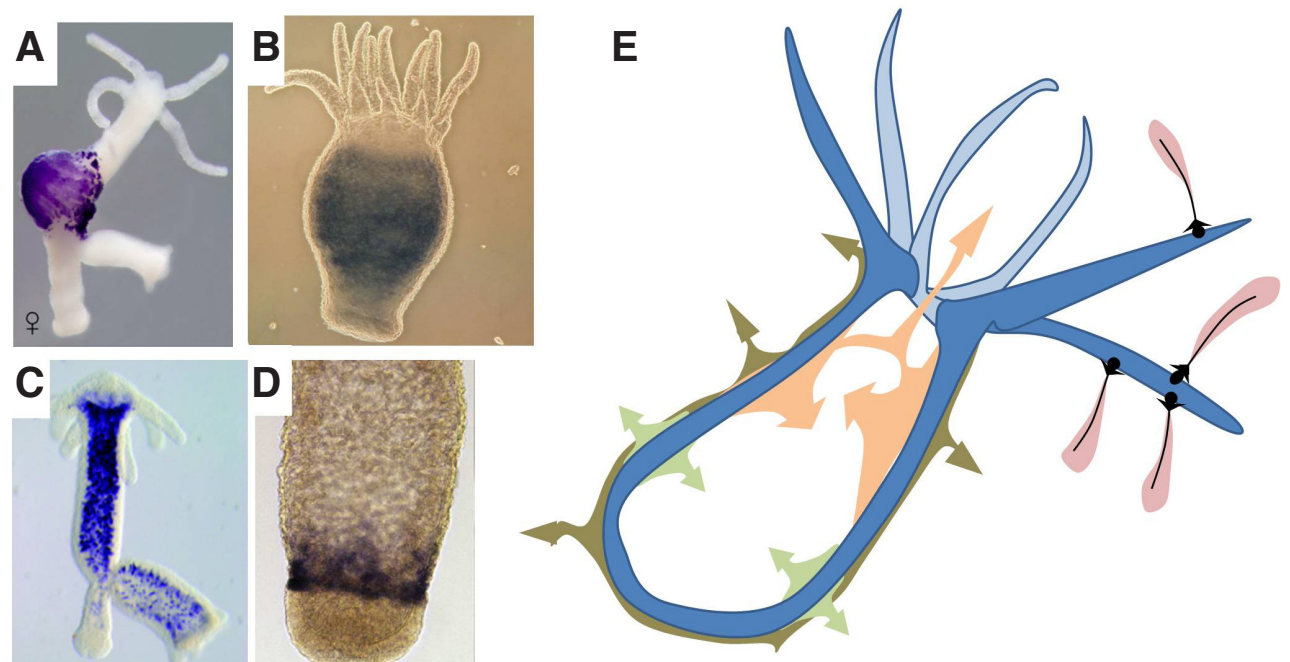

expressed at the border of the peduncle and the basal disk in PalmatoHydra robusta, and is involved in basal disk formation and maintenance. (E) Multiple bioactive compounds, secreted both as point sources (nematocysts) and across large body regions, combine to form a chemical landscape in which Hydra-microbe interactions occur. A is from (Fraune et al., 2010), B is from (Sher et al., 2008), C is from (Miller et al., 2007) and D is from (Amimoto et al., 2006) reproduced with permission from the Proc. Natl. Acad. Sci. USA, FASEB Journal, Genome Biology and Elsevier, respectively. 
fects on their surrounding ecosystems.

Cnidarians are dominant predators (and prey) in many aquatic ecosystems, and are famous for forming the largest biogenic structures on Earth - coral reefs - which are currently threatened (Pandolfi et al., 2005). Characterizing the chemical landscape of cnidarians and how it affects freshwater and marine ecosystems will require an interdisciplinary effort by ecologists, molecular and developmental biologists, biochemists, physicists, mathematicians and oceanographers or limnologists. As an experimentally tractable cnidarian, Hydra is uniquely poised to answer many of the questions on how these sessile, simple invertebrates survive in and affect their hostile aqueous environment.

\section{Acknowledgments}

We thank N. Sher for critical reading of the manuscript.

\section{References}

AMIMOTO, Y., KODAMA, R. and KOBAYAKAWA, Y. (2006). Foot formation in Hydra: a novel gene, anklet, is involved in basal disk formation. Mech Dev 123: 352-361.

ANDERLUH, G. and MACEK, P. (2002). Cytolytic peptide and protein toxins from sea anemones (Anthozoa: Actinaria). Toxicon 40: 111-124.

ANISIMOVA, M. and GASCUEL, O. (2006). Approximate likelihood-ratio test for branches: A fast, accurate, and powerful alternative. Syst Biol 55: 539-552.

AUGUSTIN, R., ANTON-ERXLEBEN, F., JUNGNICKEL, S., HEMMRICH, G., SPUDY, B., PODSCHUN, R. and BOSCH, T.C. (2009). Activity of the novel peptide arminin against multiresistant human pathogens shows the considerable potential of phylogenetically ancient organisms as drug sources. Antimicrob Agents Ch 53: 5245-5250.

BECKMANN, A., OZBEK, S. (2012). The Nematocyst: A molecular map of the cnidarian stinging organelle. Int J Dev Biol 56: 577-582.

BLAUSTEIN, L., SILBERBUSH, A., MARKMAN, S., LEWINSOHN, E., BAR, E. and COHEN, J.E. (2010). Predator-released hydrocarbons repel oviposition by a mosquito. Ecol Lett 13: 1129-1138.

BOSCH, T.C.G. and FUJISAWA, T. (2001). Polyps, peptides and patterning. Bioessays 23: 420-427.

BOtTGER, A., STRASSER, D., ALEXANDROVA, O., LEVIN, A., FISCHER, S., LASI, M., RUDD, S. and DAVID, C.N. (2006). Genetic screen for signal peptides in Hydra reveals novel secreted proteins and evidence for non-classical protein secretion. Eur J Cell Biol 85: 1107-1117.

BURNETT, A.L., DAVIDSON, R. and WIERNIK, P. (1963). On the presence of a feeding response in the nematocyst of hydra pirardi. Biol Bull 125: 226-233.

CHAPMAN, J.A., KIRKNESS, E.F., SIMAKOV, O., HAMPSON, S.E., MITROS, T., WEINMAIER, T., RATTEI, T., BALASUBRAMANIAN, P.G., BORMAN, J., BUSAM, D. et al., (2010). The dynamic genome of Hydra. Nature 464: 592-596.

CHERA, S., DE ROSA, R., MILJKOVIC-LICINA, M., DOBRETZ, K., GHILA, L., KALOULIS, K. and GALLIOT, B. (2006). Silencing of the hydra serine protease inhibitor Kazal1 gene mimics the human SPINK1 pancreatic phenotype. J Cell Sci 119: 846-857.

COHEN, L., LIPSTEIN, N. and GORDON, D. (2006). Allosteric interactions between scorpion toxin receptor sites on voltage-gated $\mathrm{Na}$ channels imply a novel role for weakly active components in arthropod venom. FASEB J 20: 1933-1935.

CONTICELLO, S.G., GILAD, Y., AVIDAN, N., BEN-ASHER, E., LEVY, Z. and FAINZILBER, M. (2001). Mechanisms for evolving hypervariability: the case of conopeptides. Mol Biol Evol 18: 120-131.

DAVID, C.N., et al. (2008). Evolution of complex structures: minicollagens shape the cnidarian nematocyst. Trends Genet. 24: 431-438.

EDWARDS, L.P., WHITTER, E. and HESSINGER, D.A. (2002). Apparent membrane pore-formation by Portuguese Man-of-war (Physalia physalis) venom in intact cultured cells. Toxicon 40: 1299-1305.

ELLIOTT, J.K., ELLIOTT, J.M. and LEGGETT, W.C. (1997). Predation by Hydra on larval fish: Field and laboratory experiments with bluegill (Lepomis macrochirus). Limnol Oceanogr 42: 1416-1423.
ESCOUBAS, P., QUINTON, L. and NICHOLSON, G.M. (2008). Venomics: unravelling the complexity of animal venoms with mass spectrometry. J. Mass Spectrom. 43: 279-295.

EWER, R.F. (1947). On the functions and mode of action of the nematocysts of Hydra. Proc. Zool. Soc. Lond 117: 365-376.

FAINZILBER, M., NAPCHI, I., GORDON, D. and ZLOTKIN, E. (1994). Marine warning via peptide toxin. Nature 369: 192-193.

FUJISAWA, T. and HAYAKAWA, E. (2012). Peptide signaling in Hydra. Int J Dev Biol 56: 543-550

FRAUNE, S., AUGUSTIN, R., ANTON-ERXLEBEN, F., WITTLIEB, J., GELHAUS, C., KLIMOVICH, V.B., SAMOILOVICH, M.P. and BOSCH, T.C. (2010). In an early branching metazoan, bacterial colonization of the embryo is controlled by maternal antimicrobial peptides. Proc Natl Acad Sci USA 107: 18067-18072.

FRAUNE, S. and BOSCH, T.C. (2007). Long-term maintenance of species-specific bacterial microbiota in the basal metazoan Hydra. Proc Natl Acad Sci USA 104: 13146-13151.

FRY, B.G., ROELANTS, K., CHAMPAGNE, D.E., SCHEIB, H., TYNDALL, J.D.A., KING, G.F., NEVALAINEN, T.J., NORMAN, J.A., LEWIS, R.J., NORTON, R.S. et al., (2009). The Toxicogenomic Multiverse: Convergent Recruitment of Proteins Into Animal Venoms. Annu Rev Genom Hum G 10: 483-511.

FRY, B.G. and WUSTER, W. (2004). Assembling an arsenal: origin and evolution of the snake venom proteome inferred from phylogenetic analysis of toxin sequences. Mol Biol Evol 21: 870-883.

GROSSART, H.P., DZIALLAS, C., LEUNERT, F. and TANG, K.W. (2010). Bacteria dispersal by hitchhiking on zooplankton. Proc NatlAcad SciUSA 107: 11959-11964.

GUINDON, S. and GASCUEL, O. (2003). A simple, fast, and accurate algorithm to estimate large phylogenies by maximum likelihood. Syst Biol 52: 696-704.

GUTIERREZ, J.M., RUCAVADO, A., ESCALANTE, T., LOMONTE, B., ANGULO, Y. and FOX, J.W. (2010). Tissue pathology induced by snake venoms: how to understand a complex pattern of alterations from a systems biology perspective? Toxicon 55: 166-170.

HOLSTEIN, T. and TARDENT, P. (1984). An ultrahigh-speed analysis of exocytosis: nematocyst discharge. Science 223: 830-833.

HWANG, J.S., OHYANAGI, H., HAYAKAWA, S., OSATO, N., NISHIMIYA-FUJISAWA, C., IKEO, K., DAVID, C.N., FUJISAWA, T. and GOJOBORI, T. (2007). The evolutionary emergence of cell type-specific genes inferred from the gene expression analysis of Hydra. Proc Natl Acad Sci USA 104: 14735-14740.

KASS-SIMON, G. and A.A. SCAPPATICCI, Jr. (2002). The behavioral and developmental physiology of nematocysts. Can. J. Zool. 80: 1772-1794.

KLUG, M. and WEBER, J. (1991). An extract from Hydra vulgaris (Cnidaria) nematocysts increases cytoplasmic Ca2+ levels in fibroblasts. Toxicon 29: 129-133.

KLUG, M., WEBER, J. and TARDENT, P. (1989a). Hemolytic and toxic properties of Hydra attenuata nematocysts. Toxicon 27: 325-339.

KLUG, M., WEBER, J. and TARDENT, P. (1989b). Hemolytic and toxic properties of Hydra attenuata nematocysts. Toxicon 27: 325-339.

KRUG, P.J. (2006). Defense of Benthic Invertebrates Against Surface Colonization by Larvae: A Chemical Arms Race Antifouling Compounds, vol. 42 (ed. FUSETANI, N. and CLARE, A. S.). Springer Berlin Heidelberg, pp.1-53.

LESH-LAURIE, G.E., DIBLASI, S.L., SUCHY, P.E. and SENTURIA, J.B. (1989). Inotropic response elicited by nematocyst contents of Hydra oligactis (Coelenterata: Hydrozoa). Comp Biochem Physiol C 94: 249-254.

LINK, J. and KEEN, R. (1995). Prey of Deep-Water Hydra in Lake-Superior. J Great Lakes Res 21: 319-323.

LOHMANN, J.U., ENDL, I. and BOSCH, T.C. (1999). Silencing of developmental genes in Hydra. Dev Biol 214: 211-214.

LOTAN, A., FISHMAN, L., LOYA, Y. and ZLOTKIN, E. (1995). Delivery of a nematocyst toxin. Nature 375: 456

LOTAN, A., FISHMAN, L. and ZLOTKIN, E. (1996). Toxin compartmentation and delivery in the cnidaria: The nematocyst's tubule as a ultiheaded poisonous arrow. J Exp Zool 275: 444-451.

MILLER, D.J., HEMMRICH, G., BALL, E.E., HAYWARD, D.C., KHALTURIN, K., FUNAYAMA, N., AGATA, K. and BOSCH, T.C. (2007). The innate immune repertoire in Cnidaria - ancestral complexity and stochastic gene loss. Genome Biol 8: R59.

MONTECUCCO, C. and ROSSETTO, O. (2000). How do presynaptic PLA2 neurotoxins block nerve terminals? Trends Biochem Sci 25: 266-270. 
MORAN, Y. and GUREVITZ, M. (2006). When positive selection of neurotoxin genes is missing. The riddle of the sea anemone Nematostella vectensis. FEBS J. 273: 3886-3892.

MORAN, Y., WEINBERGER, H., SULLIVAN, J.C., REITZEL, A.M., FINNERTY, J.R. and GUREVITZ, M. (2008). Concerted evolution of sea anemone neurotoxin genes is revealed through analysis of the Nematostella vectensis genome. $\mathrm{Mol}$ Biol Evol 25: 737-747.

MORAN, Y., GORDON, D. and GUREVITZ, M. (2009a). Sea anemone toxins affecting voltage-gated sodium channels--molecular and evolutionary features. Toxicon 54: 1089-1101.

MORAN, Y., WEINBERGER, H., LAZARUS, N., GUR, M., KAHN, R., GORDON, D. and GUREVITZ, M. (2009b). Fusion and retrotransposition events in the evolution of the sea anemone Anemonia viridis neurotoxin genes. $J$ Mol Evol 69: 115-124.

MORGENSTERN, D., ROHDE, B.H., KING, G.F., TAL, T., SHER, D. and ZLOTKIN, E. (2011). The tale of a resting gland: transcriptome of a replete venom gland from the scorpion Hottentotta judaicus. Toxicon 57: 695-703.

NUCHTER, T., BENOIT, M., ENGEL, U., OZBEK, S. and HOLSTEIN, T.W. (2006). Nanosecond-scale kinetics of nematocyst discharge. Curr Biol 16: R316-318.

OLIVERA, B.M. (2002). Conus venom peptides: Reflections from the biology of clades and species. Annu Rev Ecol Syst 33: 25-47.

PANDOLFI, J.M., JACKSON, J.B., BARON, N., BRADBURY, R.H., GUZMAN, H.M., HUGHES, T.P., KAPPEL, C.V., MICHELI, F., OGDEN, J.C., POSSINGHAM, H.P. et al., (2005). Ecology. Are U.S. coral reefs on the slippery slope to slime? Science 307: 1725-1726.

PEIREN, N., VANROBAEYS, F., DE GRAAF, D.C., DEVREESE, B., VAN BEEUMEN, J. and JACOBS, F.J. (2005). The protein composition of honeybee venom reconsidered by a proteomic approach. Biochim Biophys Acta 1752: 1-5.

PIEROBON, P. (2012). Coordinated modulation of cellular signaling through ligand-gated ion channels in Hydra vulgaris (Cnidaria, Hydrozoa). Int J Dev Biol 56: 551-565.

PUTNAM, N.H., SRIVASTAVA, M., HELLSTEN, U., DIRKS, B., CHAPMAN, J., SALAMOV, A., TERRY, A., SHAPIRO, H., LINDQUIST, E., KAPITONOV, V.V. et al., (2007). Sea Anemone Genome Reveals Ancestral Eumetazoan Gene Repertoire and Genomic Organization. Science 317: 86-94.

QUINN, B., GAGNE, F., BLAISE, C. (2012). Hydra, a model system for environmental studies. Int J Dev Biol 56: 613-625.

RANGARAJU, S., KHOO, K.K., FENG, Z.P., CROSSLEY, G., NUGENT, D., KHAYTIN, I., CHI, V., PHAM, C., CALABRESI, P., PENNINGTON, M.W. et al., (2010). Potassium channel modulation by a toxin domain in matrix metalloprotease 23. J Biol Chem 285: 9124-9136

REISA, J.J. (1973). Ecology. In Biology of Hydra, (ed. BURNETT, A. L.). Academic press, New york.

ROWAN, E.G. (2001). What does [beta]-bungarotoxin do at the neuromuscular junction? Toxicon 39: 107-118.

RUCH, R.J. and COOK, C.B. (1984). Nematocyst Inactivation during Feeding in Hydra-Littoralis. J Exp Biol 111: 31-42.

SARRAS, M. P. J. (2012). Components, structure, biogenesis and function of the Hydra extracellular matrix in regeneration, pattern formation and cell differentiation. Int J Dev Biol 56: 567-576.

SCHALOSKE, R.H. and DENNIS, E.A. (2006). The phospholipase A2 superfamily and its group numbering system. Biochim Biophys Acta 1761: 1246-1259

SHER, D., FISHMAN, Y., ZHANG, M., LEBENDIKER, M., GAATHON, A., MANCHENO, J.M. and ZLOTKIN, E. (2005a). Hydralysins, a new category of beta-pore-forming toxins in cnidaria. J Biol Chem 280: 22847-22855.

SHER, D., KNEBEL, A., BSOR, T., NESHER, N., TAL, T., MORGENSTERN, D. COHEN, E., FISHMAN, Y. and ZLOTKIN, E. (2005b). Toxic polypeptides of the hydra--a bioinformatic approach to cnidarian allomones. Toxicon 45: 865-879.

SHER, D., FISHMAN, Y., MELAMED-BOOK, N., ZHANG, M. and ZLOTKIN, E. (2008). Osmotically driven prey disintegration in the gastrovascular cavity of the green hydra by a pore-forming protein. FASEB J 22: 207-221.

SHER, D. and ZLOTKIN, E. (2009). A hydra with many heads: protein and polypeptide toxins from hydra and their biological roles. Toxicon 54: 1148-1161.

SOLLOD, B.L., WILSON, D., ZHAXYBAYEVA, O., GOGARTEN, J.P., DRINKWATER, R. and KING, G.F. (2005). Were arachnids the first to use combinatorial peptide libraries? Peptides 26: 131-139.

TAKAHASHI, T., MUNEOKA, Y., LOHMANN, J., LOPEZDE HARO, M.S., SOLLEDER G., BOSCH, T.C.G., DAVID, C.N., BODE, H.R., KOIZUMI, O., SHIMIZU, H. et al., (1997). Systematic isolation of peptide signal molecules regulating development in hydra: LWamide and PW families. Proc. Natl. Acad. Sci. USA 94: 1241-1246.

TARDENT, P. (1995). The cnidarian cnidocyte, a high-tech cellular weaponry. Bioessays 17: 351-362

TERLAU, H., SHON, K.J., GRILLEY, M., STOCKER, M., STUHMER, W. and OLIVERA B.M. (1996). Strategy for rapid immobilization of prey by a fish-hunting marine snail. Nature 381: 148-151.

THOMAS, R.G. and POUGH, F.H. (1979). The effect of rattlesnake venom on digestion of prey. Toxicon 17: 221-228.

TREMBLEY, A. (1744). Memoirs pour l'histoire des polypes (second memoire). The Boxwood Press, Pacific Grove, CA.

VALENTIN, E., GHOMASHCHI, F., GELB, M.H., LAZDUNSKI, M. and LAMBEAU, G. (2000). Novel Human Secreted Phospholipase A2 with Homology to the Group III Bee Venom Enzyme. J Biol Chem 275: 7492-7496.

WEBER, J., KLUG, M. and TARDENT, P. (1987). Some physical and chemical properties of purified nematocysts of Hydra attenuata Pall. (Hydrozoa, Cnidaria). Comp Biochem Physiol B 88: 855-862.

WIEBRING, A., HELMHOLZ, H., SöTJE, I., LASSEN, S., PRANGE, A. and TIEMANN H. (2010). ANew Method for the Separation of Different Types of Nematocysts from Scyphozoa and Investigation of Proteinaceous Toxins Utilizing Laser Catapulting and Subsequent Mass Spectrometry. Mar Biotechnol 12: 308-317.

WULLSCHLEGER, B., NENTWIG, W. and KUHN-NENTWIG, L. (2005). Spider venom: enhancement of venom efficacy mediated by different synergistic strategies in Cupiennius salei. J Exp Biol 208: 2115-2121

YAN, L., LEONTOVICH, A., FEI, K. and SARRAS, M.P., JR. (2000). Hydra metalloproteinase 1: a secreted astacin metalloproteinase whose apical axis expression is differentially regulated during head regeneration. Dev Biol 219: 115-228.

YAN, L., POLLOCK, G.H., NAGASE, H. and SARRAS, M.P., JR. (1995). A25.7 x 10(3) $\mathrm{M}(\mathrm{r})$ hydra metalloproteinase (HMP1), a member of the astacin family, localizes to the extracellular matrix of Hydra vulgaris in a head-specific manner and has a developmental function. Development 121: 1591-1602.

ZHANG, M., FISHMAN, Y., SHER, D. and ZLOTKIN, E. (2003). Hydralysin, a nove animal group-selective paralytic and cytolytic protein from a noncnidocystic origin in hydra. Biochemistry 42: 8939-8944. 


\section{Further Related Reading, published previously in the Int. J. Dev. Biol.}

A polymorphic, thrombospondin domain-containing lectin is an oocyte marker in Hydractinia: implications for germ cell specification and sex determination

Brahim Mali, R. Cathriona Millane, Günter Plickert, Marcus Frohme and Uri Frank

Int. J. Dev. Biol. (2011) 55: 103-108

The role of alpha-amidated neuropeptides in hydroid development--LWamides and metamorphosis in Hydractinia echinata

Günter Plickert, Eva Schetter, Nicole Verhey-Van-Wijk, Jörg Schlossherr, Marlis Steinbüchel and Martin Gajewski

Int. J. Dev. Biol. (2003) 47: 439-450

Allogeneic interactions in Hydractinia: is the transitory chimera beneficial? Sharon Gild, Uri Frank and Ofer Mokady

Int. J. Dev. Biol. (2003) 47: 433-438

\section{Ca2+-ions and pattern control in Hydra}

Stefanie Zeretzke, Fernando Pérez, Kirsten Velden and Stefan Berking

Int. J. Dev. Biol. (2002) 46: 705-710

Autoaggressive, multi-headed and other mutant phenotypes in Hydractinia echinata (Cnidaria: Hydrozoa)

Werner A Müller

Int. J. Dev. Biol. (2002) 46: 1023-1033

5 yr ISI Impact Factor $(2010)=2.961$

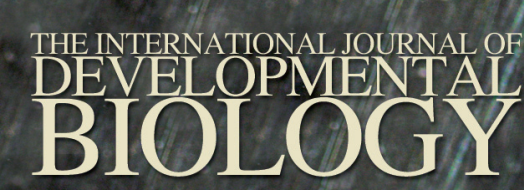

Volume 56 Nos. 1/2/3
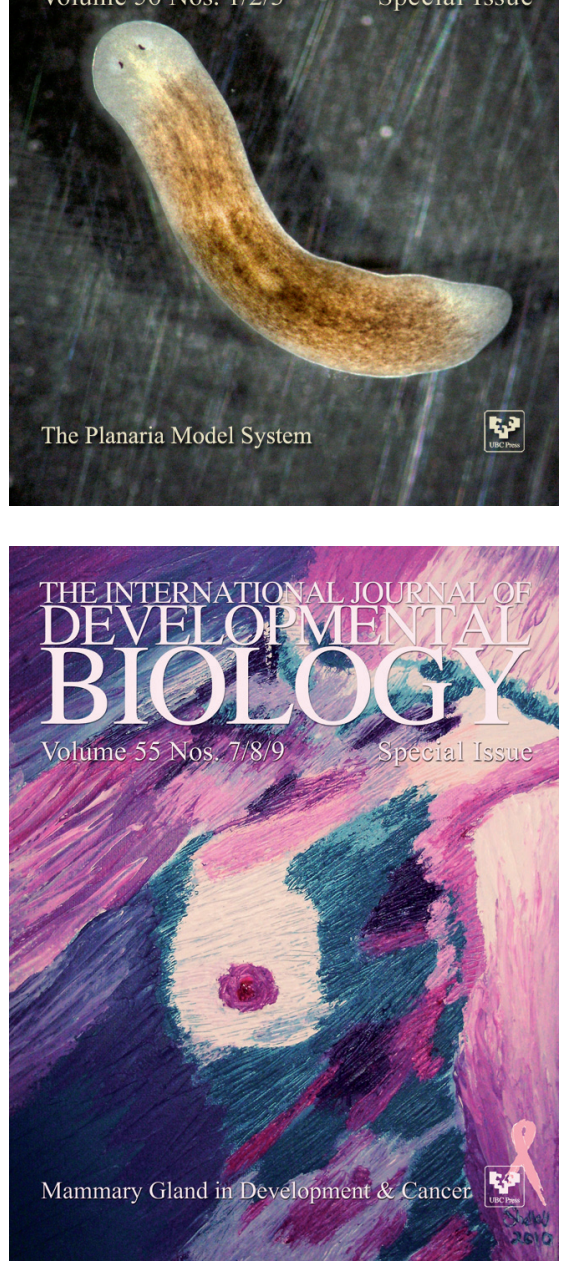

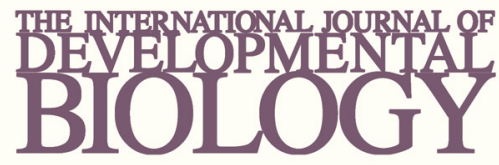

Volume 54 Nos. 6/7
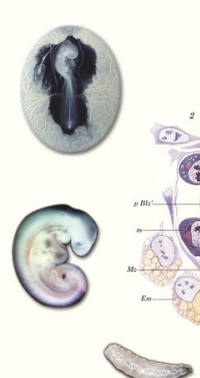

Developmental Hematopoiesis
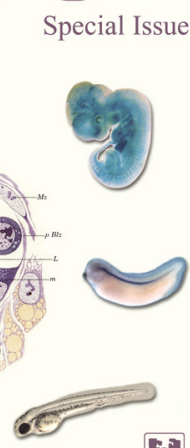

$\$$

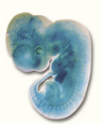

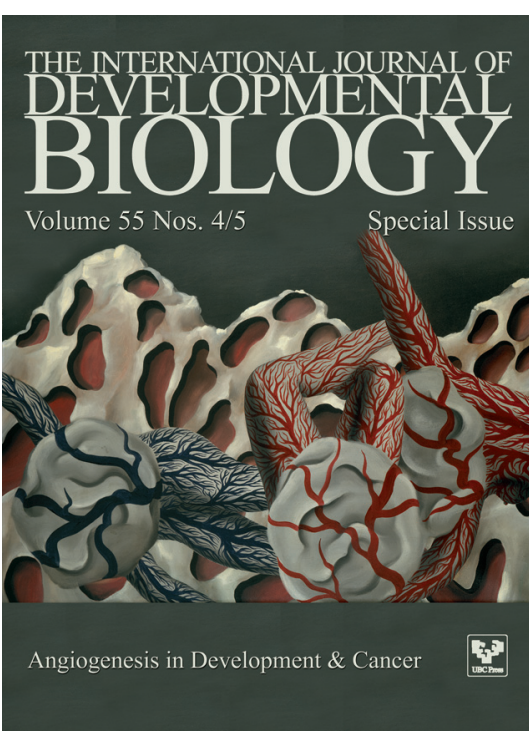

